\title{
$C A U-B A U-K A N$ : A STORY OF THE CONTRIBUTION OF TIONGHOA TO THE NATION-BUILDING OF INDONESIA
}

\section{Yohanes Hartadi '}

\begin{abstract}
Ethnic and racial riots still happen in Indonesia. There must be a deeply-rooted reason for that. Remy Sylado's Cau-BauKan concerns with a racial enmity between the pribumi and the Tionghoa (Indonesian Chinese). The enmity is growing from the old times when the Dutch and the Japanese colonized the country. They spreaded false ideas against the Tionghoa among the pribumi. The Dutch also had the Tionghoa live in a particular area so that they were isolated from the interraction with the pribumi. Most pribumi do not understand these causes, they even produce stereotypes for generations. Cau-Bau-Kan tries to counter the stereotypes saying that the Tionghoa did not contribute anything for the nation-building of Indonesia.
\end{abstract}

Key words : Ethnic, the pribumi, the Tionghoa.

\section{INTRODUCTION ${ }^{2}$}

We are happy that our national badminton team could defend Thomas Cup for the fifth time this year. It was a great achievement as Thomas Cup is a symbol of badminton supremacy in the world. With the win, Indonesia has been noted as the record holder of the Thomas Cup winning team. However, just before the team left for Hong Kong where the competition

t. Yohanes Hartadi, SS. is a lecturer of the Faculty of Letters, Soegijapranata Catholic University, Semarang.

2 I am indebted to Benny D. Setianto of the Faculty of Law for making the reference books available 
was carried out, a ridiculous thing happened to Hendrawan, a world badminton champion and a silver medal winner in 2002 Olympic Games in Sydney, could not go through the government bureaucracy smoothly. He could not have his and his wife's SBKRI (Surat Bukti Kewarganegaraan Republik Indonesia-Citizenship Letter of Indonesian Republic) passed for months.

The problem above is only one example of how the Indonesian Chinese are treated by the citizens (hereafter pribumi) who, as they say, cherish the values of a just and civilized humanity. The writer takes Hendrawan's case as an example instead of another for particular reason. Hendrawan has been playing as a national badminton player for years and he has defended the country's pride through sport. Is such meritorious citizen not worthy to receive equal service from the country? How about the ordinary Indonesian Chinese? ${ }^{3}$

The issue of Indonesian Chinese (hereafter Tionghoa ${ }^{4}$ ) is attracting many people's attention. In Indonesian literature, one of the authors who concems with Tionghoa is Remy Sylado. The name sounds musical and finny as it is a pseudo-name for Yapi Tambayong. Remy was born in Makassar, South Sulawesi and he spent his childhood in Semarang, Central Java. For this reason he knows much about Semarang city. Remy obtained his good reputation as an artist after he pioneered the poetry style so called 'mbeling' movement, poetry trial in Bandung, and produced great theatres such as Jesus Christ Super Star in 1980s. Along with other poets Remy created mbeling (naughty) which aimed to break through the aesthetic power of 'serious poetry' found in the works of Sapardi Joko Damono and

3 Even Hendrawan's brother has been waiting for 20 years but he has not received the letter. This is a classic problem because similar case happened to Tan Joe Hok in 1971. Despite his merit in winning Thomas Cup for the first time and gold medal in the Asian Games 1962, and being the first Indonesian to win All England, Joe Hok still had to deal with K-I model form which was named Surat Keterangan Pelaporan Warga Negara Republik Indonesia. Another case happened to Ivana Lie, a female badminton player who was well known in 1970s. Ivana had to fight to get her status of Indonesian Citizen (WNI) for five years. On an occasion to meet President Soeharto, she was asked by the president what did she want as a reward for her achievement? Ivana answered that she wanted to get a piece of Kartu Tanda Penduduk (identification). Finally, Ivana became an Indonesian Citizen (WNI) officially in 1982.

- The overseas Chinese are also called hoakiao or huagiao. In Indonesia this term refers to the totok Chinese ( $x$ in ke) 
Goenawan Mohamad. Remy said that it would be a danger if people too much glorify a certain aesthetic and thought that poems could only be produced by great poets. This situation would discourage people to be an artist. He gave an example of Horison, a literary magazine published in Jakarta, which crowned a work 'literary' or 'non-literary'. Being mbeling is thus a must and it starts from the wind of freedom blown by rock culture. Later he asks his friends to rebel creatively against literary texts which are 'too polite'.

We might still have young Remy's works in mind like Orexas (Organisasi Sex Bebas-Free Sex Organization) or Gila Lobang Gali Lobang. It was the age of popular novels in which many romantic novels were written by Indonesian authors. At present Remy is less mbeling than when he was young. He is taking another way now. After the age of reformation, Remy is producing works with Chinese atmosphere such as plays Siau Ling and Toar dan Lumimuut and a novel Ca-Bau-Kan. However, he is not only writing about Tionghoa but also writing about the Dutch who lived in East Indies in his work Paris van Java which is being published in Koran Tempo. Another work is Sam Poo Kong which he writes for Suara Merdeka. Remy said that he put sympathy to the Tionghoa because they were oppressed by the New Order government. He mentioned a restaurant on Jalan Bojong, Semarang, was knocked down for the reason that it used Chinese names for the menu (Suara Merdeka Daily, 2002: xii). This is a starting point for Remy to write a part of the country's history which enables us to learn something from Tionghoa. We can leam from people who have been living hundreds of years in Indonesia and who have certain ignored knowledge because of sere prejudice.

Ca-Bau-Kan has been filmed and released in 2002 after the Chinese New Year (Imlek). It was the second novel, which was published by Kepustakaan Populer Gramedia. The novel has been published six times until now but this is not the major reason why the writer chooses $\mathrm{Ca}$-Bau$K a n$ as an object of study. It is the exposure of the roles of Tionghoa in the history of Indonesian independence movement in the novel, which motivates the writer to make an analysis. In the Sekapur Sirih part (introductory part), it is written that the novel denies stereotype opinion saying that Tionghoa did not contribute to the history of Indonesian independence (Sylado, 2001: v). This article is going to talk about the counter-opinion that is divided into some parts. In the first part of the analysis the writer is trying to find out the 
stereotypes, which are spreading among the pribumi. It must be accomplished first because this is the root of the problem. Then to counter the stereotype the writer is presenting the facts about the contribution of Tionghoa to the nation building in the second part of the analysis. After that literary exploration on Ca-Bau-Kan is going to be done in the last part of the analysis.

A literary work is something multi-interpretable, so we can read and interpret it from various angles. New Criticism as a model of the last phase of modernist literary study treats a literary work as a literary work, so it is separated from the outside world. Study is done on the work itself and on the intrinsic elements of the work. That's why a literary work is treated as merely a 'text' without intertwining it with other 'contexts' in the society. Budi Dharma (2001: p.18) wrote

Consciousness that encourages the birth of cultural studies and aspiration that encourages the birth of postmodernism, on the contrary, are but consciousness and aspiration, which grow from the reality outside literature. The emphasis of cultural studies is consciousness of cultural studies as a must, while the emphasis of postmodernism is rejection of establishment inasmuch as it is not suitable for the reality of the postmodernists. Hence, literary studies, is not to be done only on literary works or text, but also on its context in the society.

The sociology of literature, for instance, does not treat literary work as a mere literary work or literary text, but it pays heed on its relationship to the social context. So, literary text is thus a document of social problems." Literary criticism shifts from the text, from the aesthetics values in a literary work, and has to leap onto the extrinsic elements. Therefore, both in cultural studies as the twin of postmodernism, the aesthetics values of a literary work are ignorable. Context is more important than text since text is nothing but the hands of context.

\section{ANALYSIS}

1. Stereotypes of Tionghoa

According to Scollon and Scollon (2000:171-174), stereotypes can be distinguished into two types: the negative stereotypes and the positive

3 In the twentieth century, literary canonization is based partly on the external elements. Literature as a documentation of reality is an essential condition for a work to be called a masterpiece. 
ones. Any form of stereotyping is potentially an obstruction to successful intercultural communication because it will blind us to real differences that exist between the participants in a discourse. The most obstructive form of stereotyping, however, is also sometimes called negative stereotyping. Scollon and Scollon further elaborate the steps how people produce negative stereotypes. In such a case, the first step is to contrast two cultures or two groups on the basis of some single dimension. The second step in negative stereotyping is to focus on this artificial and ideological difference as a problem for communication. The third step, then, is to assign a positive value to one strategy or one group and a negative value to the other strategy or group. The fourth and final step is to regeneralize this process to the entire group. One reasserts the original binaristic contrast as a negative group contrast (2001: 171). No two groups are either polar opposites or exactly identical. The problem of negative stereotyping is one of seeing members of different groups as being polar opposites. The problem of positive stereotyping is one of seeing members of different groups as being identical. In either case, it is a problem of stereotyping which arises from making a comparison on the basis of a single, binary dimension of analysis.

Scollon and Scollon also said that when the grouping is based on falsely combining one's own group and some other group, we would call it the solidarity fallacy. For instance, an American woman falsely included in her group, American women, with Chinese on the belief that they had the emphasis on relationship in common, while ignoring the major differences between their groups. When the person making the false grouping is doing so in reference to two other groups, we would call that the lumping fallacy. For example, when westerners consider all Asians to be members of the same group without taking into consideration the major differences among these groups, this would be called the lumping fallacy (2001: 173-174). In both cases, positive stereotyping occurs when the person making the categorization takes the characteristics he or she used to make the stereotyping as positive, while negative stereotyping results when the basis of comparison was considered to be negative.

Let us now see the pribumi's common opinion on the Tionghoa. You see that from the introductory remarks I have been using the term pribumi to refer to Indonesian indigenous people. It is important to trace the origin of the term because it has significant meaning on the production of negative stereotype of Tionghoa. The terms bumiputera (in Malaysian spelling) and 


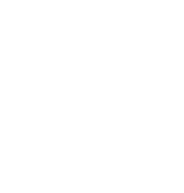

pribumi are local translations for Sanskrit words. Bumi means world or soil in Malay and Indonesian, whereas putera may be translated as prince or it is more commonly used as a polite call for a son. A Javanese expression wong (which means man/woman) pribumi (that combines a Javanese prefix pri-with a loan word from Sanskrit, bumi) means indigenous people. The word pribumi is borrowed from Javanese, and it is used to refer to indigenous people in Indonesia (Siddique and Suryadinata, 1999: 105).

The term bumiputera and pribumi were used to distinguish the indigenous from the non-indigenous in the colonialized land and were popularized in 1920s and 1930s. The term bumiputera had been popularized by press media of the peranakan (Indonesian Chinese/Tionghoa) and the pribumi in the East Indies since the second decade of the twentieth century. In fact, earlier reference for the use of the term can be found in the name of the first pribumi life insurance in the East Indies (the Onderlings Levensverzekering Mij. Boemipoetera) which was founded in 1912 (Siddique and Suryadinata, 1999: 108). Despite being debatable that the terms were popularized to meet the need for a name to distinguish the indigenous : (pribumi) from the other (non-pribumi), the growth of the terms were supported by the colonial policies. British concept of Malay people as putra tanah air (sons of the soil/bumiputera) encourages us to use them more frequently. The dichotomy of both terms was kept by the collonial in two ways: firstly, by popularizing immigration or at least by bringing immigrant workers, and secondly, with policies that suggested both immigrants and pribumi to assume themselves as a collective society (Siddique and Suryadinata, 1999: 110).

In the East Indies the social structure was organized based on racial consideration. The Tionghoa had to live in a particular area (Zone Systemwijkenstelsel) and they had to carry a journey letter to leave the area (passenstelsel). With this legal policy, the Dutch collonial prevented the Tionghoa to assimilate with the pribumi (Suryadinata, 1994: 21). Mona Lohanda (2001: 1-2) also writes that in common with many other Western colonies in the East, the colonial administration adopted a policy of segregation, which created social stratification based on race and religion. In major cities of Java (Batavia, Semarang, Surabaya) and Makassar, the practice of segregation was very apparent. In Batavia, the population was divided into three main groups as follows: (1) European, including German, Swedish, French, Danish, British, Portuguese, and others; (2) Vreemde 
Oosterlingen of Foreign Asistics, i.e. Chinese, Arabs, Armenians, Indians, Persians, and others; (3) Natives (pribumi), namely Javanese, Balinese, Ambonese, Buginese, Timorese, Malays and many others (Lohanda, 2001: 1-2). Suryadinata said that the division indicates their status. The Europeans were people of the first class, the Foreign Asistics were the middle class and the Natives (pribumi) were the lower class (1994: 21).

From the history of the colonial period, common people both Tionghoa and pribumi have inherited a collective viewpoint which dominate their attitudes and actions. Such collectivism is perpetuated by the Indonesian government in public policies. It appears in the National Constitution about the presidency and the regulation for civil servants. Such policies and the inherited social status plant the seed of suspicion and hatred between the two groups. The pribumi felt threatened in economy while the Hoakiau felt that the pribumi are savage people. The pribumi pass on the hatred to the next generations so that their bind to the collectivism keeps tight. Living in the middle of the condition, the pribumi stands firmly on the ground of stereotype. The stereotype system could be our own private tradition, a defence for our position in the society (Lipfman, 1998: 87). By spreading the stereotype of Tionghoa, the pribumi are trying to discredit them.

Charles A. Coppel (1994: 26-27) compiles some stereotypes of Tionghoa that are found in Indonesian publication. The Tionghoa (Tionghoa) like living in their own groups, they make a distance from social interaction and prefer living in a particular area. They are stick to the culture of their motherland. In good times, their loyalty is doubtful and in hard times, they are enemies of the pribumi. Their option for Indonesia is superficial, they pretend doing everything for opportunism reasons rather than true feeling to defend the country and the people. Such opportunism is the specific character of people who aim to gain only money, trading, and business. They are different from pribumi that possess a sense of dedication to ideals. Having been given an advantageous status by the Dutch, the Tionghoa dominate the country's economy, oppress the Indonesian mass, and hinder the resurrection of the national or pribumi enterprisers. Dissatisfied with their dominant status, they are involved in economic subversion as they are expert in bribery and smuggling.

It is a historical fact that some Tionghoa were acting as traitors after the Independence. Poh An Tui, for example, was an organization that was armed by the Dutch and became their henchmen in fighting the Indonesian 
soldiers. Some others welcomed the return of the Dutch's power after Japanese's occupation (Toer, 1998: 141-142). This individual action was generalized as the group's by the pribumi. During the revolution, the Dutch did not only make physical battles but also psychological battles. They knew that they had planted a sentiment among the pribumi toward Tionghoa. They were excited with this condition so that they provoked enmity among the revolutionary pribumi soldiers. The Dutch drew two benefits from this: first, they expanded their territory and second, they exterminated Tionghoa (Toer, 1998: 162). Indeed, the pribumi revolutionary soldiers were provoked and massacred Tionghoa.

So ugly is the image of the Tionghoa that their good side is fading out. The merits of their generations are only dimming light on the mind of the pribumi. It is common almost in the entire archipelago with the exception in certain regions like West Kalimantan in which the Tionghoa, the Malay, and the Dayak people have been assimilated and assume themselves as tripods of a stove. ${ }^{6}$ Unfortunately, it is only in West Kalimantan. The unity of Indonesia is effective only in the geography while mentally they are apart. Until this point the witer deduces that the Indonesian pribumi still live in the past and they are still mentally-colonized regardless of being independent from the Dutch.

\section{The Contribution of the Tionghoa to the Nation Building}

All Indonesians know that de juro Indonesia was free from the Dutch colonialism on August 17, 1945. The independence was gained with much tears and blood. All elements of the society, military and civil were involved. To gain independence, Indonesians fought together regardless of their race and ethnicity. In this section, the writer will expose the roles of Tionghoa in the nation building of Indonesia particularly those toward the 1945 revolution.

Pramoedya Ananta Toer in Tionghoa di Indonesia wrote that Tionghoa can be our best companies in the fight for independence. Pramoedya

- After the 1965 affair, particularly on December 20", 1966 Brigadir General Ryamizad (whose son is now a General and newly-appointed as Chief Staff of Indonesian Army) ordered the chairperson and other leaders of a local Tionghoa organization, Chung Hwa Kung Hui, and other Tionghoa people who are 'directly or indirectly' involved in PKI (Indonesian Communist Party) or the coup de etat in 1965. It was reponted that there had been hundreds of Tionghoa were expelled from the region. Read: Coppel, Charles A. Tionghoa Indonesia Dalam Krisis. Jakarta: Pustaka Sinar Harapan. 1994. p. 216 
collected so many data on the matter that he divided the contributions of Tionghoa into: the period before the Dutch colonization, the period of colonization, the period of Japanese occupation, and during the August Revolution. In this article the writer will focus on the period toward independence, starting from the awakening of Indonesian nationalism.

The true Indonesian nationalism emerged after the rebellion of the Indonesian Communist Party (PKI) in 1926-1927 was crushed by the Dutch colonial. The affair ended the status of PKI as a legal party in the East Indies as well as the end of the Ethical Policy. The new movement was initialled by new intellectual class some of whom were educated in Dutch universities. They used to be active in the students organization called Perhimpoenan Indonesia. The vision of the new movement was more defined, Independent Indonesia (Indonesia Merdeka). In Holland, not only was there a pribumi nationalist organization but also a Tionghoa organization. It was named $\mathrm{CHH}$ Netherland, an organization consisted of peranakan Tionghoa students which was founded in 1917. The headquarter was Leiden. Most peranakan Tionghoa students, both high school students and university students, joined in. Despite their er.notional bond with China, it seemed that they paid more attention on their status in the East Indies. They disfavoured the position of Tionghoa which was lower that the Europeans. Chinese nationalism made them sympathize with the fight of the pribumi to fight for independence. Most of them went back to the East Indies after finishing their study as they considered the East Indies as their land rather than China. ${ }^{7} \mathrm{CHH}$ Netherlands showed their sympathy for the struggle of Perhimpoenan Indonesia (PI) in 1928 through their magazine, Chung Hwa Hui Tsa Chih (CHHTC). Their relationship was getting closer. The magazine also wrote an article on Mohammad Hatta (who later became the first Indonesian Vice President) and supported his nationalist's outlook.

The emotional bond between Tionghoa and pribumi was strengthened with the spread of Pan-Asianism (Asia Raya) idea by dr. Sun Yat Sen. This bore an opinion saying that the urgent task of the Tionghoa was to assist the pribumi to fight against the white as they were similarly Asians. Tjoe Bou San, the Chief Editor of Sin $P o$, argued that Tionghoa and pribumi were the

7 Suryadinata, Leo. Polirik Tionghoa Peranakan di Jawa. Jakarta: Pustaks Sinar Harapan. 1994, pp. 56-57

- Suryadinata, Leo. Polirik Tionghoa Peranakan di Jawa. Jakarta: Pustaka Sinar Harapan. 1994, pp.79-80 
similarly Asians and should support each other in gaining their independence. For the reason, he employed many pribumi journalists and printed many news on nationalism movement written by them. Indonesian nationalists were also eager to co-operate with $\operatorname{Sin} P o$ as they still lack of mass media to spread the idea of nationalism. It was recorded that Sukarno, the leader of PNI, visited Sin Po office in 1923. ${ }^{9}$ Sin Po, Keng Po, and Sin Jit Po made an assault to Chung Hwa Hui. Those media criticized them for taking side on the Dutch's power. As they were the loyal onderdanen for the Dutch, consequently they opposed the Indonesians (pribumi). Ending at this point, we see that the roles of the Tionghoa in building the Indonesian nation were on the level of progressive ideas and they spread the ideas of nationalism through their mass media.

Were Tionghoa involved in movements? We will find the data below. Pramoedya writes that Tionghoa were involved in many strikes against the Dutch factories, despite their vague Indonesian nationalism. Tionghoa participated in many organizations along with the pribumi such as Sarekat Laoet dan Coedang (in Semarang), Sarekat Kaoem Boeroeh Pelaboehan (Jakarta and St.rabaya), and Sarekat Boeroeh Goela. Tionghoa played their roles in rebellions led by these organizations in 1925. They were involved actively in many strikes in 1925 and furthermore they spread their ideas through the press which at the time was called Melayu-Tionghoa. ${ }^{10}$ Actually, more roles were played by Tionghoa before the beginning of nationalism. "I

\section{The Narrative}

Ca-Bau-Kan is a novel of mixed atmospheres, romanticism, intrigues, and nationalism. The latest mentioned will be discussed in this section. The novel is started with a four-page prologue which introduces the narrator,

- Suryadinata, Leo. Mencari Idenritas Nasional dari Tjoe Bou San sampai Yap Thiam Hien. Jakarta: Penerbit LP3ES. 1990, pp. 14-15. It is said that Sukamo told Tjoe that he appreciated Tionghoa taking the road of Chinese Nationalism who supported Indonesia regardless of the danger rather than those who were becoming Indonesians only for personal profits.

10 Toer, Pramoedya Ananta. Tionghoa di Indonesia. Jakarta: Penerbit Garba Budaya. 1998. p. 150

"Read lbid. Pramoedya compiles many data about the supports of the Tionghoa in the book especially during the fights by traditional leaders like Sultan Agung of Mataram, Pangeran Diponegoro (Yogyakarta), and Untung Surapati. With those leaders. Tionghoa participated as soldiers, smugglers of rifles as well as spies. 
Mrs. G.P.A. Dijkoff, who comes from the Netherlands to Indonesia to search for her parents' identity, and her granddaughter Anneke Dijkoff. The major characters introduced in the prologue are Tan Peng Liang and Siti Nurhayati, who was called Tinung since she was a kid. There are two characters with the same name, Tan Peng Liang. The first one is Tan Peng Liang coming from Gang Tamin Bandung who owns a banana plantation in Sewan Tangerang and the other comes from Gang Pinggir Semarang who dominates the trade of tobacco and opium in Glodok. On page one, right in the middle of the narration we find: Ini pembelaan. Bukan hanya pembetulan (This is a defence, not only a correction). The sentence means so much to the writer. If we read only the first page, we may find that the sentence refers to Tinung who is considered a woman of low pride, because she is a ca-bau-kan. In Hok-Kian language, the word means nothing more than 'woman'. However, it has the second meaning: a pribumi woman who is married by a Tionghoa (Tionghoa) man but not considering the legal status of the Dutch East Indies.

If we have finished reading the whole novel, the sentence draws a deeper meaning. Who is defended? We will explore the novel to find the answer and then support it. As mentioned above, there are two Tan Peng Liangs. This is a problem that Mrs. Dijkoff has to solve. With her arrival in Batavia (Jakarta), she has to find out which one of two is her father because the two are very different in characters: Tan Peng Liang of Tangerang is a traitor but the other is a partner for Indonesian soldiers in fighting the Dutch. As this is not the heart of the matter, we will discuss it no more.

If we trace the origin of Tan Peng Liang Semarang (hereafter Tan Peng Liang), we will find that the blood of assimilation is flowing in him. His father is a Tionghoa and his mother is a Javanese from the Raden Mas Ngabehi Sasradiningrats of Surakarta. It should also be understood that his mother is a real mother, not only a ca-bau-kan for his father because it is not told that Tan Tiang Tjing (the father) has another wife. As a result of his deep respect to his father, the teacher for everything for him, he follows the same way, getting married with Tinung who is a pribumi. It does not mean that Tan Peng Liang abandons his first wife to get married to Tinung. His first wife has been completely paralysed, while he wants a daughter. So, he marries Tinung with the reason and more his first wife gives him consent to.

Tan Peng Liang's blood line with the pribumi leads him to get close to his cousin, Mr. R.M. Soetardjo Rahardjo, a nationalist movement activist and member of Partai Nasional Indonesia. On an occasion, they meet in 
Semarang and Soetardjo says his gratitude to Tan Peng Liang for helping the nationalist movements financially.

"Thank you for your financial aid for our movements here," Soetardjo Rahardjo said.

"It's nothing," Tan Peng Liang replied. "If you have problems Mas, just let me know and I surely will help you."

"Yes I will. On behalf of VC', all friends say their thanks, matur nuwun." (Cau-Bau-Kan, 2001: 90)

Tan Peng Liang's decision to help the nationalist is inseparable from Tan Tiang Tjing's education. It was Tan Tiang Tjing who teaches him to do it. It is recorded that he was jailed by the Dutch for giving financial aid for nationalists' meeting that was headed by Soetardjo.

At the time, Tan Tiang Tjin, Tan Peng Liang's father, or Tan Soen Bie's grandfather, was jailed. He was prosecuted by the Dutch for giving financial aid for the party meeting headed by R.M. Soetardjo Rahardjo which was held in Salatiga. (Cau-Bau-Kan, 2001: 103)

Personally, Tan Peng Liang opposes Kong Koan, a Chinese Council founded by the Dutch to administer the Chinese in the Dutch East Indies. ${ }^{13} \mathrm{He}$ considers them as a threat from the totok who assume themselves deserved respect from the peranakan. Not only does he oppose Kong Koan, but also the Dutch whom he thinks as death images.

1 Vaderlandsche Club, a temporary name for nationalist movement since the banning of PNI (Partai Nasional Indonesia which was founded by Soekamo in Bandung)

13 The term Chineesch Bestuur, namely local nule over the Chinese in the Dutch East Indies, frequently appears in Dutch colonial records, particularly in the 1920's when the government discussed its termination. In the eyes of the Dutch, this Chineesch Bestuur was represented by, or composed of, the Chinese officers and the Chinese Council. The terms refer only to rule over the Chinese communties in Java and Madura. The institution of Chinese officers was in fact set up by the Dutch when they appointed the first Chinese captain on 11 October 1619. It existed untui 1936, with the exception of the Chinese officers in Batavia. Both institutions, the Chinese officers and the Chinese Council (called by the Dutch government, the Chineesche Raad, while for the Chinese community it was Kong Koan) worked together in managing and supervising the Chinese community. For further information about the Chinese Council read: Lohanda, Mona. The Kapiran Cina of Batavia 1837-1942. Jakarta: Penerbit Djambatan. 2001, chapter IV. 
We both hate the oppression by the Whites who feel superior all over the world." (Tan Peng Liang)

"But......." (Soetardjo)

"Hold" (Tan Peng Liang)

"So, what?" (Soetardjo)

"We have to resist the oppression, Mas." (Tan Peng Liang) (Cau-Bau-Kan, 2001: 211)

This condition brings some light to our mind, that stereotypes and generalization over the Tionghoa are not valid. Kong Koan is a representation of the totok Chinese. On the other hand, Tan Peng Liang is a representation of the peranakan Chinese. In spite of their common Chinese origin, they are different in their development. They hold their own customs, ideas, and principles.

There was a popular opinion that the Tionghoa are partners of the Japanese during the Japanese occupation in Indonesia. We have to be wise in distinguishing an individual's action from the group's. Of course there was always a traitor among us, whether he was a Tionghoa or pribumi. Remy Sylado continues the narration to the period of Japanese occupation in Java. Soetardjo, Tan Peng Liang's cousin, becomes the member of Peta squad (Pembela Tanah Air). With his intelligence, he could recommend Tan Tiang Tjing be the member of Java Hokaido, an institution intended to communicate with the Indonesian Independence-supporting organizations which was founded and guided by Gunseikanbu (Japanese military government). However, they do not become dolls on the stage of Japanese theatre. They are fighting in silence.

So far, it has not been discovered by the Japanese that Soetardjo Rahardjo and Tan Tiang Tjing are people of ants in the pants. It is because both men secretly share information with BPKP (Badan Pembantoe Keloewarga Pradjoerit) known as Bodjong 89 (now Jl. Pemuda) who was hot nationalists as well as revolutionaries. (Cau-Bau-Kan, 2001: 282)

When Japan cities has been bombed with atomic bombs by the allied forces, the Caesar surrenders to them. However, the Japanese forces in Indonesia are very tough. They do not surrender in some places. The condition is getting worse when the Dutch soldiers are coming back. So, Indonesian soldiers have to fight two enemies at once. The biggest problem is they lack of guns. In this difficult situation, Tan Peng Liang becomes the solution. He 




supplies guns for the Indonesian soldiers. It is not important to talk about how he buys the guns. He does that by smuggling them from Bangkok. However, it is not only for personal profits but it involves gut and it is too risky. He will be killed by the Japanese patrols if he meets them on the sea. Moreover, Tan Peng Liang is conscious to contribute something to Indonesia.

"Our friends are expecting your role," Soetardjo Rahardjo said.

"How can I?" Tan Peng Liang replied. "My talent is but trading."

"That's the point," said Soetardjo Rahardjo. "Once you told me you could deal with guns business in Bangkok."

"It is true. What do you want me to do?"

".....How do we get guns with affordable price?."

"Basically I need two persons who have enough gut to sail with me." (CauBau-Kan, 2001: 340)

Pramoedya in Tionghoa di Indonesia makes a note that it is not true to say that during the Japanese occupation, the Tionghoa helped the older brother (the Japanese) as far as we regard it not as a group's action. Even, when the Japanese had trodden on the Indonesian land, the Tionghoa's shops were the first to be broken into. ${ }^{14}$ Thus, empathy to the pribumi is growing among the Tionghoa. We can answer the question at the beginning of the analysis now, it is the Tionghoa who is defended by the author. He defends them from the generalization by people.

\section{CONCLUSION}

The recent ethnic and racial riots are regrets for us. They cost too much pain and bring no benefits. It only brings pseudo-nationalism, pseudosolidarity, and pseudo-ethnic pride. More people are turning into reluctant people to learn and to read. What is the benefit of reading thick novel? From Ca-Bau-Kan we learn that the Tionghoa contributes many things for the nation-building of Indonesia. They assimilate with the local people (the pribumi) without leaving their own cultures which is represented in the story by Tan Tiang Tjing and his son Tan Peng Liang who are married to pribumi women. They give financial aid for the nationalists' organizations regardless of the punishment from the Dutch. They supply guns for the Indonesian soldiers despite the risk of death. They become informers for the Indonesian nationalists. It is possible that many more contributions the Tionghoa do that are not told in the novel. Citing Abdurrahman Wahid's speech, we are lucky to have Tionghoa brothers. We must count on this thing further. The 
professionalism of the Tionghoa is seen on the economy life, trading, and industries. These are truly professionals although some are only depending on the powerful people of the country. If we keep on being fussy and doubtful over Tionghoa, Indonesian nation will never be a great nation. By reading the novel or watching the movie, we hope that people will be more aware of the danger of stereotypes. We hope that we can separate individual deeds from group deeds.

\section{BIBLIOGRAPHY}

Coppel, Charles A. Tionghoa Indonesia Dalam Krisis. Jakarta: Pustaka Sinar Harapan, 1994.

Darma, Budi. Ironi Si Kembar Siam. Jakarta: KALAM Jurnal Kebudayaan No. 18. p. 171, 2001.

Lippmann, Walter. Opini Umum-Antara Rekayasa dan Realitas.Jakarta: Yayasan Obor Indonesia, 1998

Lohanda, Mona. The Kapitan Cina of Batavia 1837.1942. Jakarta: Penerbit Djambatan, 2001.

Pejuang Itu Tetap Warga Kelas Dua (Tan Joe Hok). Harian Limum KOMPAS, Monday, $29^{\text {th }}$ April 2002, p. 6.

Scollon, Ron and Scollon, Suzanne Wong. Intercultural Communication.A Discourse Approach. Massachussers: Blackwell Publishers Inc., 2001

Siddique, Sharon and Suryadinata, Leo. Bumiputera and Pribumi. Nasionalisme (Pribumisme) Ekonomi di Malaysia dan Indonesia. Jakarta: PT Pustaka LP3ES Indonesia, 1999.

Suara Merdeka Daily. Sunday, June 9, 2002 p. XIl Remy Sylado: Jangan Berjarak dari Orang Cina.

Suryadinata, Leo. Mencari Identitas Nasional dari Tjoe Bou San sampai Yap Thiam Hien. Jakarta: Penerbit LP3ES, 1990

Suryadinata, Leo. Politik Tionghoa Peranakan di Jawa. Jakarta: Pustaka Sinar Harapan, 1994.

Sylado, Remy. Ca-Bau-Kan. Jakarta: Kepustakaan Populer Gramedia (KPG), $4^{\text {th }}$ ed., July 2001.

Toer, Pramoedya Ananta. Hoakiao di Indonesia. Jakarta: Penerbit Garba Budaya. 1998.

Warga Tionghoa Membawa Profesionalisme. Harian Umum KOMPAS, Monday, $6^{\text {th }}$ May 2002. 